\title{
Identification and activity of active compound of bamboo leaves (Bambusa vulgaris Schrad ex.J.C) ethanolic extract against diabetic ulcers gram-negative bacteria from diabetic ulcer's patient
}

\section{Identifikasi kandungan senyawa aktif dan uji aktivitas antibakteri ekstrak etanol daun bambu (Bambusa vulgaris Schrad ex.J.C) terhadap bakteri patogen gram negatif isolat pasien luka diabetes}

\author{
Pratiwi Apridamayanti
}

Jurusan Farmasi, Fakultas Kedokteran, Universitas Tanjungpura Corresponding author: apridamayanti.pratiwi@gmail.com

\begin{abstract}
Background: Bamboo leaves (Bambusa vulgaris Schrad ex.J.C) are plants that are known to have pharmacological activity, one of which is to have antibacterial activity. Diabetic Foot Ulcers (DFU) is one chronic complication of diabetes mellitus. DFU is open sores on the surface of the skin that can be accompanied by local tissue death. Infection that is not appropriately treated in patients can cause amputation. Improper use of antibiotics can cause resistance events. A resistance that occurs in Proteus mirabilis, Pseudomonas aeruginosa, and Escherichia coli in isolates from DFU patients encourages researchers to look for alternative antibiotics from natural resources.

Objective: Determine the profile of secondary metabolites by thin-layer chromatography, foam index, total phenols, total flavonoids and the antibacterial activity of bamboo ( $B$. vulgaris) through the antibacterial with clear zone value of bamboo leaf ethanol extract against bacteria E. coli, P. aeruginosa, and P. mirabilis.

Method: Phenol, flavonoid, and triterpenoid test using TLC method. Saponin tests were carried out using foam index, fish index, and hemolytic index test methods. Total flavonoid testing using Chang method and total phenol method using the Follin Ciocalteau reagent then proceed using a spectrophotometer. Test the antibacterial activity using the agar diffusion method.

Results: Chromatographic profile, phenol, flavonoid, and triterpenoid compounds were obtained; saponin index obtained foam index of 333; fish index of 200; and the hemolytic index of 1.11. The total phenol test was $16.05 \pm 3.12 \%$ and the total flavonoid was $2.42 \pm 0.44 \%$. Antibacterial activity test obtained MIC values of $60 \mathrm{mg} / \mathrm{ml}$ for E. coli bacteria; $100 \mathrm{mg} / \mathrm{ml}$ for the bacterium P. aeruginosa; and $30 \mathrm{mg} / \mathrm{ml}$ of $P$. mirabilis.

Conclusion: The content of secondary metabolites found in the ethanol extract of bamboo leaves were flavonoid, phenol, saponin and triterpenoids. Ethanol extract of bamboo leaves has a the potential to produce antibacterial activity against gram-negative pathogenic bacteria isolated from diabetic wound patients
\end{abstract}

Keywords: Bambusa vulgaris Schrad ex.J.C, total phenol, total flavonoid, MIC

\section{Intisari}

Latar belakang: Daun bambu (Bambusa vulgaris Schrad ex.J.C) merupakan tumbuhan yang diketahui memiliki aktivitas farmakologis, salah satunya adalah memiliki aktivitas antibakteri. Ulkus Kaki Diabetik (UKD) adalah salah satu bentuk komplikasi kronik diabetes melitus berupa luka terbuka pada permukaan kulit yang dapat disertai adanya kematian jaringan setempat. Infeksi yang tidak ditangani dengan baik pada penderita dapat menyebabkan terjadinya kasus amputasi. Penggunaan antibiotik yang tidak tepat dapat mendorong peristiwa resistensi. Resistensi yang terjadi pada Proteus mirabilis, Pseudomonas aeruginosa dan Escherichia coli pada isolat pasien UKD mendorong peneliti untuk mencari alternative antibiotik yang bersumber dari bahan alam.

'ujuan: Mengetahui profil metabolit sekunder secara kromatografi lapis tipis, indeks busa, total fenol, total flavonoid dan aktivitas antibakteri bambu (B. vulgaris) 
melalui nilai Kadar Hambat Minimum (KHM) ekstrak etanol daun bambu terhadap bakteri E.coli, P. aeruginosa dan P. mirabilis.

Metode: Uji Fenol, Flavonoid dan Triterpenoid menggunakan metode KLT. Pengujian saponin dilakukan dengan metode uji indeks busa, indeks ikan, dan indeks hemolitik. Pengujian Flavonoid total menggunakan metode Chang dan Fenol total dengan menggunakan reagen Follin Ciocalteau kemudian dilanjutkan dengan menggunakan spektrofotometer. Uji aktivitas antibakteri dengan menggunakan metode difusi agar.

Hasil: Pada profil kromatografi diperoleh senyawa fenol, flavonoid, dan triterpenoid; indeks saponin diperoleh indeks busa sebesar 333; indeks ikan sebesar 200; dan indeks hemolitik sebesar 1,11. Pengujian fenol total sebesar 16,05 $\pm 3,12 \%$ Asam Galat Ekuivalen (AGE)dan Flavonoid total sebesar 2,42 $\pm 0,44 \%$ Kuarsetin Ekuivalen (KE). Uji aktivitas antibakteri diperoleh nilai MIC sebesar $60 \mathrm{mg} / \mathrm{ml}$ untuk bakteri E. coli ; $100 \mathrm{mg} / \mathrm{ml}$ untuk bakteri P. aeruginosa; dan $30 \mathrm{mg} / \mathrm{ml}$ P. mirabilis.

Kesimpulan: Kandungan metabolit sekunder yang terdapat pada ekstrak etanol daun bambu adalah flavonoid, fenol, saponin, dan triterpenoid. Ekstrak etanol daun bambu memiliki potensi menghasilkan aktivitas antibakteri terhadap bakteri patogen gram negatif isolat pasien luka diabetes

Kata kunci : Bambusa vulgaris Schrad ex.J.C, fenol total, flavonoid total, KHM

\section{Pendahuluan}

Di Indonesia, bambu umumnya digunakan masyarakat sebagai olahan makanan. Masyarakat memanfaatkan kulit batang dan batang bambu muda (rebung) sebagai olahan makanan, sedangkan daun bambu belum banyak dimanfaatkan. Daun bambu merupakan tumbuhan yang diketahui memiliki aktivitas farmakologis, salah satunya adalah memiliki aktivitas antibakteri. Menurut penelitian Mulyono, et al., 2012 diketahui bambu petung (Dendrocalamus asper) memiliki aktivitas antibakteri terhadap E. coli (Mulyono et al., 2012). Pada penelitian yang dilakukan oleh Macherla, et al., 2012 diketahui bahwa ekstrak metanol daun B. vulgaris memiliki aktivitas antibakteri terhadap Bacillus subtilis dan Sterptococcus aeureus (Macherla et al., 2012). Skrining fitokimia yang telah dilakukan oleh Annafiatuzakiyah, 2016 pada ekstrak etanol daun B. vulgaris mengandung flavonoid, polifenol, triterpenoid dan saponin.

Luka kaki diabetes adalah suatu kondisi dimana terjadi kelainan tungkai kaki bawah akibat diabetes melitus yang tidak terkendali disebabkan olah gangguan pembuluh darah, gangguan persyarafan dan adanya infeksi (Misnadiarly, 2006). Infeksi yang terjadi disebabkan oleh bakteri aerob maupun anaerob (Tambunan, 2007). Data yang diperoleh oleh Abidin, 2013 di Klinik Spesialis Perawatan Luka Kitamura diantara 800 pasien diabetes, 470 pasien diantaranya menderita komplikasi (Ulkus Kaki Diabetes) UKD (Abidin, 2013). Hasil penelitian oleh Sari dan Apridamayanti., 2015 diketahui bakteri yang menginfeksi pasien UKD di Klinik Spesialis Perawatan Luka Kitamura adalah P. mirabilis (35,90\%), P. aeruginosa $(10,26 \%)$ dan E. coli $(5,13 \%)$. Penelitian yang dilakukan Sari dkk., 2018 diketahui bahwa E. coli resisten terhadap antibiotik sefadroksil. P. aeruginosa resisten terhadap antibiotik sefadroksil dan amikasin; $P$. mirabilis resisten terhadap antibiotik sefadroksil dan klindamisin (Sari, R., Apridamayanti, 2015), (Sari, Apridamayanti and Puspita, 2018; Apridamayanti and Sari, 2019). 
Penelitian yang sudah dilakukan di India menyatakan bahwa ekstrak air dan ekstrak etanol dari daun bambu jenis Bambusa arundinaceae dapat menghambat pertumbuhan bakteri E. coli dan P. aeruginosa (Singh et al., 2010). Penelitian Wardayanie dan Sitorus., 2012 menyatakan bahwa bambu andong (Gigantochloa pseudorundinaceae) dan bambu ampel (B. vulgaris) yang mengalami peristiwa pirolisis, dimana cairan hasil sampingan yang digunakan pada penelilitian diketahui memiliki aktivitas antibakteri pada Pseudomonas sp., E. coli dan Salmonella sp. (Wardayanie and Sitorus, 2012). Terjadinya resistensi yang terjadi pada $P$. mirabilis, $P$. aeruginosa dan E. coli mendorong peneliti untuk mencari alternative antibiotik yang bersumber dari bahan alam. Tujuan dari penelitian ini adalah mengetahui profil metabolit sekunder secara kromatografi lapis tipis, indeks busa, total fenol, total flavonoid dan aktivitas antibakteri bambu (B. vulgaris) melalui nilai Kadar Hambat Minimum (KHM) ekstrak etanol daun B. vulgaris terhadap bakteri E. coli, P. aeruginosa dan P. mirabilis.

\section{Metode}

\subsection{Deskripsi bahan dan teknik pengumpulan sampel}

Bahan-bahan yang digunakan dalam penelitian ini adalah $\mathrm{AlCl}_{3}$ (Merck), alkohol $70 \%$, alumunium foil, $\mathrm{CH}_{3} \mathrm{COOH}$ glasial (Merck), asam galat (Sigma-aldrich), asam klorida pekat (Merck), akuades, $\mathrm{FeCl}_{3}$ (Merck), Dimethyl Sulfoxide (DMSO) 10\% (Merck), etanol 96\%, $\mathrm{H}_{2} \mathrm{SO}_{4}$ pekat (Merck), $\mathrm{CH}_{3} \mathrm{Cl}$ (Merck), $\mathrm{NaCl}$ (Merck) 0,9\%, larutan standar Mc. Farland (Oxoid), Muller Hinton Agar (Oxoid), pereaksi Folin Ciocalreau (Sigma-aldrich), $\mathrm{NaCO}_{3}$ ( Merck, metanol (Merck), kuersetin (Sigma-aldrich), asam galat (Sigma-aldrich), safranin, siprofloksasin $5 \mu \mathrm{g} / \mathrm{ml}$ (sebagai bahan pembuatan kontrol positif).

Tanaman bambu diperoleh dari Dusun Sekajang, Desa Suruh Tembawang, Kecamatan Entikong Kabupaten Sanggau provinsi Kalimantan Barat. Bakteri uji yang digunakan pada penelitian ini antara lain kultur murni E. coli, P. aeruginosa, P. mirabilis yang diperoleh dari isolat pasien ulkus diabetikum dan disimpan sebagai koleksi Laboratorium Biologi Farmasi Badan Pengelola Fakultas Farmasi Universitas Tanjungpura Pontianak.

\subsection{Jalannya penelitian}

\subsubsection{Pengolahan sampel}

Pengolahan bahan dilakukan dengan melakukan sortasi basah daun bambu (B. vulgaris), kemudian daun dirajang tipis kemudian ditiriskan. Selanjutnya daun bambu (B. vulgaris) yang telah dirajang kemudian dikeringkan di suhu kamar kurang lebih antara $20-25^{\circ} \mathrm{C}$ hingga diperoleh simplisia kering. Pembuatan serbuk simplisia dengan cara penghalusan ukuran partikel dan diayak dengan menggunakan ayakan ukuran 40 mesh. Serbuk kemudian di 
maserasi dengan etanol 96\%, kemudian disaring dan dilakukan penguapan pelarut dengan rotary evaporator sehingga diperoleh ekstrak kental (DepKes R.I., 2000).

\subsubsection{Profil kromatografi metabolit sekunder}

Uji dilakukan terhadap ekstrak bambu untuk mengetahui profil kromatografi dengan menggunakan Kromatografi Lapis Tipis (KLT) terhadap senyawa fenol, flavonoid, dan triterpenoid. Pelarut yang digunakan adalah butanol: asam asetat : air (4:1:5) untuk senyawa fenol dan flavonoid, serta n-heksana : etil asetat (8:2) untuk senyawa triterpenoid (Harborne, J., 2006).

\subsubsection{Indeks saponin}

Pengujian indeks saponin pada ekstrak etanol daun bambu dilakukan dengan cara melakukan uji indeks busa, uji indeks ikan dan uji hemolisis. Dibuat konsentrasi ekstrak sebesar 0,5\% yang digunakan pada uji indeks busa, uji indeks ikan dan uji hemolisis. Uji indeks busa dilakukan dengan mengukur tinggi busa pada tabung reaksi, uji indeks ikan menggunakan 2 ekor anak ikan mujaer, dan uji hemolisis menggunakan darah sapi (DepKes R.I., 2000)

\subsubsection{Penentuan kadar fenol dan flavonoid total}

Uji kandungan fenol dan flavonoid total dilakukan dengan menggunakan spektrofotometer. Pada uji fenol total diambil sebanyak $10 \mathrm{mg}$ ekstrak dilarutkan dalam 10 $\mathrm{mL}$ akuades. Ambil $1 \mathrm{~mL}$ kemudian direaksikan dengan Follin Ciocalticeu dan $\mathrm{NaCO}_{3}$ diinkubasi pada suhu $50^{\circ} \mathrm{C}$ selama 5 menit, diukur dengan spektrofotometer pada panjang gelombang $757 \mathrm{~nm}$, dengan menggunakan larutan pembanding asam galat (Hanani., 2015). Uji kandungan flavonoid total dengan menimbang sebanyak 25 mg ekstrak dilarutkan dalam $25 \mathrm{~mL}$ akuades. Ambil $2 \mathrm{~mL}$ larutan dan direaksikan dengan $\mathrm{AlCl}_{3}$ dan $\mathrm{CH}_{3} \mathrm{COONa}$ diinkubasi selama 30 menit, diukur dengan spektrofotometer pada panjang gelombang $425 \mathrm{~nm}$, dengan menggunakan larutan pembanding kuersetin (Hanani., 2015).

2.3.5 Uji aktivitas antibakteri

\subsubsection{Kultur bakteri uji}

Biakan bakteri dari E. coli, P. aeruginosa, P. mirabilis yang telah lolos kaji etik dengan No. 1054/UN2.9/DL/2018 oleh Etik Fakultas Kedokteran Universitas Tanjungpura, strain utama diambil dari biakan agar miring bakteri dengan jarum Ose steril lalu diinokulasi pada permukaan media MHA miring, kemudian diinkubasikan pada suhu $37^{\circ} \mathrm{C}$ selama 24 jam (Septiana, 2011). Koloni bakteri E. coli, P. aeruginosa dan P. mirabilis diambil dari stok kultur menggunakan jarum ose steril kemudian disuspensikan ke dalam $10 \mathrm{~mL}$ larutan $\mathrm{NaCl}$ 0,9\% steril lalu diinkubasikan pada suhu $37^{\circ} \mathrm{C}$ sampai didapat kekeruhan (ICMR, 2009). Kekeruhan yang diperoleh kemudian disetarakan secara visual dengan larutan standar Mc. Farland 0,5 (ICMR, 2009). 


\subsubsection{Uji aktivitas antibakteri}

Bakteri E. coli, P. aeruginosa dan P. mirabilis di inokulasi dengan menggunakan jarum Ose pada permukaan media yang telah padat. Selanjutnya dipipet sebanyak $25 \mu \mathrm{L}$ ekstrak etanol daun B. vulgaris dengan variasi konsentrasi pada bakteri E. coli dan P. aeruginosa yaitu 120 $\mathrm{mg} / \mathrm{mL}, 100 \mathrm{mg} / \mathrm{mL}, 80 \mathrm{mg} / \mathrm{mL}, 60 \mathrm{mg} / \mathrm{mL}, 40 \mathrm{mg} / \mathrm{mL}$ dan $20 \mathrm{mg} / \mathrm{mL}$; variasi konsentrasi bakteri $P$. mirabilis yaitu70 mg/mL, $60 \mathrm{mg} / \mathrm{mL}, 50 \mathrm{mg} / \mathrm{mL}, 40 \mathrm{mg} / \mathrm{mL}, 30 \mathrm{mg} / \mathrm{mL}$ dan 20 $\mathrm{mg} / \mathrm{mL}$ kemudian diteteskan pada cakram kertas dan diletakkan di media yang telah diinokulasi. Kultur diinkubasi dalam inkubator pada suhu $37^{\circ} \mathrm{C}$ selama 18 - 24 jam. Setelah itu diukur diameter daerah hambatan (zona jernih) pertumbuhan di sekitar cakram kertas menggunakan jangka sorong (ICMR, 2009). Pegujian aktivitas pada bakteri E. coli, P. aeruginosa dan P. mirabilis dilakukan dengan replikasi sebanyak 3 kali pada setiap bakterinya dengan variasi konsentrasi yang sama.

\section{Hasil dan pembahasan}

Menurut penelitian yang telah dilakukan oleh Annafiatuzzakia, 2017 telah diketahui skrining fitokimia terhadap ekstrak etanol daun bambu diketahui memiliki kandungan flavonoid, polifenol, saponin dan triterpenoid (Annafiatuzakiah, 2017). Pada penelitian ini diperoleh pola kromatografi dengan menggunakan plat lapis tipis silika gel 254 fase gerak nbutanol: air: asam asetat (4:5:1) dengan penampak bercak $\mathrm{AlCl}_{3}$ dan $\mathrm{FeCl}_{3}$ untuk senyawa flavonoid dan Fenol. Pada senyawa triterpenoid menggunakan fase gerak n-hexan:etil asetat (8:2) dengan penampak bercak vanillin asam sulfat. Hasil uji dapat dilihat pada Gambar 1, 2, 3 dan Tabel 1.

Tabel 1. Pemisahan ekstrak etanol daun B. vulgaris dengan kromatografi lapis silica gel 254

\begin{tabular}{cccccccc}
\hline No & Spots & $\mathbf{2 5 4} \mathbf{~ n m}$ & $\mathbf{3 6 6} \mathbf{~ n m}$ & $\mathbf{A l C l}_{\mathbf{3}}$ & $\mathbf{F e C l}_{\mathbf{3}}$ & $\begin{array}{c}\text { Vanilin } \\
\text { Asam Sulfat }\end{array}$ & $\mathbf{R f}$ \\
\hline 1 & 1 & Hitam & $\begin{array}{c}\text { Hitam } \\
\text { latar biru } \\
\text { Hitam }\end{array}$ & Kuning & - & - & 0,56 \\
2 & 2 & Kitaning & - & - & 0,44 \\
3 & 3 & Hitam & $\begin{array}{c}\text { Hitam } \\
\text { latar biru } \\
\text { Hitam }\end{array}$ & - & Hitam & - & 0,67 \\
4 & 4 & Hitam & Hitam & - & 0,54 \\
5 & 5 & Hitam & Biru & - & - & Biru-ungu & 0,68 \\
\hline
\end{tabular}




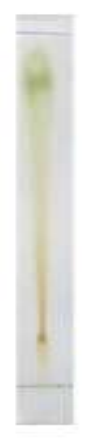

a

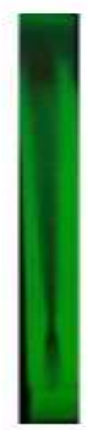

b

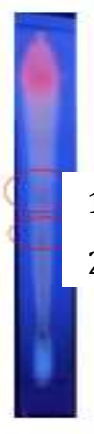

c

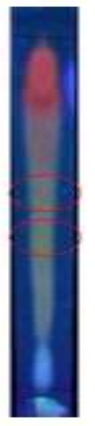

d

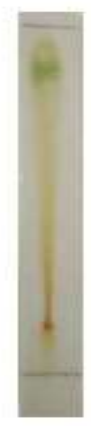

e

Gambar 1. Profil senyawa flavonoid dengan KLT silika gel 254 dengan fase gerak air : asam asetat : nbutanol (5: 1:4)

Keterangan: $\quad \mathrm{a}=$ Pengamatan pada sinar tampak

$\mathrm{b}=$ Pengamatan pada UV $254 \mathrm{~nm}$

$\mathrm{c}=$ Pengamatan pada UV light $366 \mathrm{~nm}$

$\mathrm{d}=$ Pengamatan pada UV light $366+\mathrm{AlCl}_{3}$

$\mathrm{e}=$ Pengamatan pada sinar tampak $+\mathrm{AlCl}_{3}$

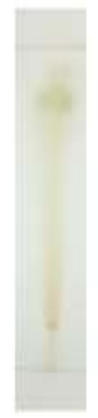

a

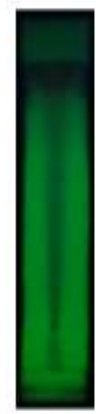

b

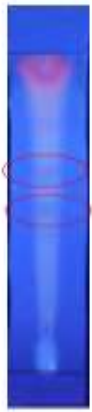

c

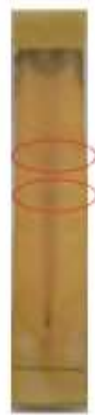

d

Gambar 2. Profil kromatografi senyawa fenol ekstrak etanol daun B. vulgaris dengan fase gerak air : asam asetat: n-butanol (5: 1:4)

Keterangan: $\quad \mathrm{a}=$ Pengamatan pada sinar tampak

$\mathrm{b}=$ Pengamatan pada UV $254 \mathrm{~nm}$

$\mathrm{c}=$ Pengamatan pada UV light $366 \mathrm{~nm}$

$\mathrm{d}=$ Pengamatan pada sinar tampak $+\mathrm{FeCl}_{3}$

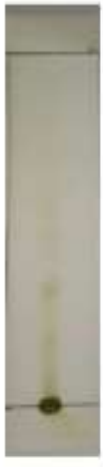

a

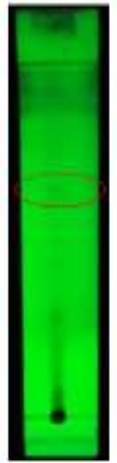

b

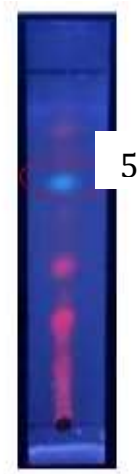

c

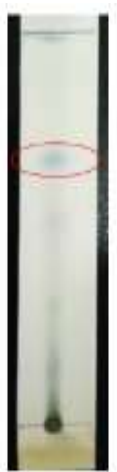

d

Gambar 3. Profil kromatografi senyawa triterpenoid ekstrak etanol daun B. vulgaris dengan fase gerak nhexan : etil asetat (8:2)

Keterangan : $a=$ Pengamatan pada sinar tampk

$\mathrm{b}=$ Pengamatan pada UV $254 \mathrm{~nm}$

c= Pengamatan pada UV light $366 \mathrm{~nm}$

$\mathrm{d}=$ Pengamatan pada sinar tampak $+\left(\right.$ Vanillin $\left.-\mathrm{H}_{2} \mathrm{SO}_{4}\right)$ 
Identifikasi kandungan saponin dengan menggunakan indeks busa, indeks ikan dan hemolitik, disajikan pada Tabel 2. Dari hasil uji tersebut diketahui ekstrak etanol daun bambu memiliki senyawa saponin.

Tabel 2. Identifikasi saponin pada ekstrak etanol B. vulgaris

\begin{tabular}{ccc}
\hline No & Indeks saponin & Hasil \\
\hline 1 & Indeks busa & 333 \\
2 & Indeks ikan & 200 \\
3 & Indeks hemolitik & 1,11 \\
\hline
\end{tabular}

Penentuan kadar fenol dan flavonoid total menggunakan spektrofotometer UV/Vis dengan pembanding senyawa asam galat dan kuarcetin. Hasil uji diperoleh bahwa ekstrak etanol daun B. vulgaris adalah 16,05 $\pm 3,12 \%$ AGE (Asam Galat Ekuivalen) dan 2,42 $\pm 0,44 \%$ KE (Kuersetin Ekuivalen).

Pengujian aktivitas antibakteri dengan melihat besaran KHM yang diberikan oleh ekstrak daun bambu (B. vulgaris) terhadap bakteri Gram negatif yaitu bakteri E. coli, P. aeruginosa dan P. mirabilis. Penentuan besarnya KHM yang diperoleh dengan menggunakan metode disk diffusion. Pada metode ini senyawa uji yaitu ekstrak etanol daun B. vulgaris yang terdapat pada cakram akan berdifusi ke dalam media agar. Parameter yang dilihat adalah terbentuknya zona bening di sekitar cakram (Alfian and Susanti, 2012). Uji antibakteri terhadap bakteri uji dapat dilihat pada Gambar 3.

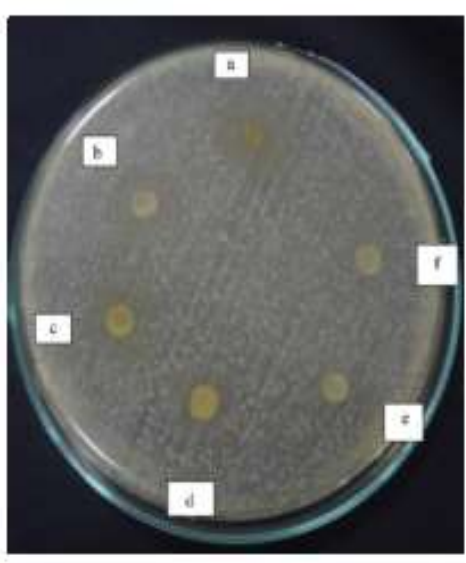

E.Coli

Konsentrasi $(\mathrm{mg} / \mathrm{ml})$

$\mathrm{a}=120$

$\mathrm{b}=100$

$\mathrm{c}=80$

$\mathrm{d}=60$

$\mathrm{e}=40$

$\mathrm{f}=20$

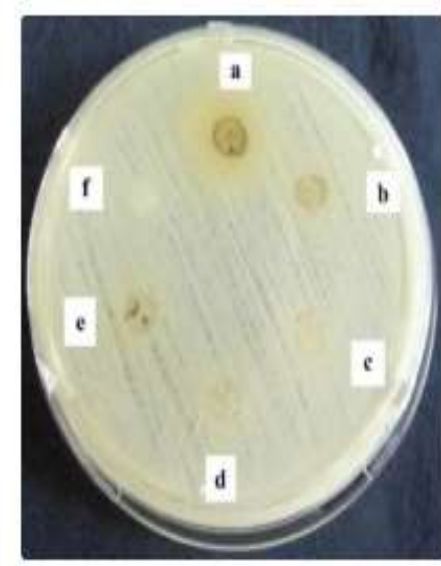

P.aeuroginosa

Konsentrasi $(\mathrm{mg} / \mathrm{ml})$

$\mathrm{a}=70$

$\mathrm{b}=60$

$\mathrm{c}=50$

$\mathrm{d}=40$

$\mathrm{e}=30$

$\mathrm{f}=20$

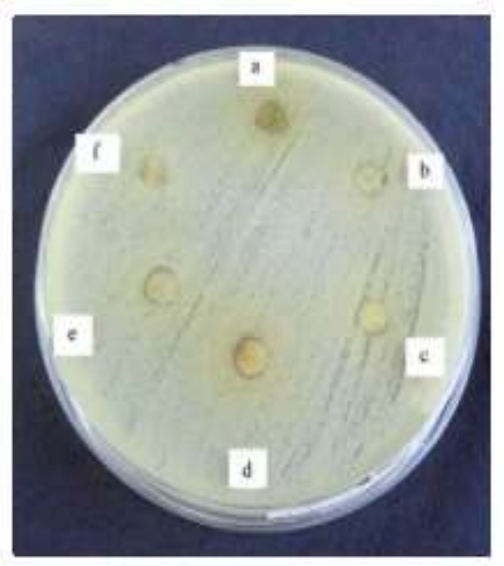

P.mirabilis

Konsentrasi $(\mathrm{mg} / \mathrm{ml})$

$\mathrm{a}=120$

$\mathrm{b}=100$

$\mathrm{c}=80$

$\mathrm{d}=60$

$\mathrm{e}=40$

$\mathrm{f}=20$

Gambar 4. Uji aktivitas antibakteri ekstrak etanol daun B. vulgaris 
Hasil dari pengujian aktivitas antibakteri menunjukkan bahwa ekstrak etanol daun $B$. vulgaris memberikan zona hambat yang berbeda-beda di setiap konsentrasinya. Peningkatan konsentrasi ekstrak daun bambu berbanding lurus dengan peningkatan diameter zona hambat, konsentrasi ekstrak yang meningkat maka semakin banyak komponen bioaktif yang terkandung dalam di dalam ekstrak. Zona hambat yang terbentuk adalah zona bening yang menandakan bahwa adanya aktivitas antibakteri pada ekstrak daun bambu (B. vulgaris). Pengujian pada bakteri E. coli menghasilkan konsentrasi hambat minimum pada konsentrasi $60 \mathrm{mg} / \mathrm{mL}$ diperoleh zona hambat $9,46 \mathrm{~mm} \pm 0,47$ dan pada konsentrasi yang lebih kecil yaitu $40 \mathrm{mg} / \mathrm{mL}$ dan $20 \mathrm{mg} / \mathrm{mL}$ tidak terdapat zona hambat sehingga dapat dipastikan MIC ekstrak etanol daun bambu pada bakteri E.coli adalah $60 \mathrm{mg} / \mathrm{mL}$. Pengujian pada bakteri P. mirabilis dengan konsentrasi $30 \mathrm{mg} / \mathrm{mL}$ diperoleh zona hambat 6,41 $\mathrm{mm} \pm 0,07$ dan konsentrasi $20 \mathrm{mg} / \mathrm{mL}$ tidak ditemukan adanya zona hambat. Bakteri P. aeruginosa menghasilkan zona hambat terkecil pada konsentrasi $100 \mathrm{mg} / \mathrm{mL}$ dengan rata-rata zona hambat $6,42 \mathrm{~mm} \pm 0,38$ dan pada konsentrasi yang lebih kecil yaitu $80 \mathrm{mg} / \mathrm{mL}, 60 \mathrm{mg} / \mathrm{mL}, 40 \mathrm{mg} / \mathrm{mL}, 20 \mathrm{mg} / \mathrm{mL}$ tidak terdapat zona hambat sehingga MIC ekstrak etanol daun B. vulgaris pada bakteri P. mirabilis adalah 30 mg/mL dan P. aeruginosa adalah $100 \mathrm{mg} / \mathrm{mL}$. Hasil pengujian dapat dilihat pada Tabel 4.

Tabel 4. Diameter zona hambat uji aktivitas antibakteri ekstrak etanol daun B. vulgaris

\begin{tabular}{|c|c|c|c|c|c|c|c|c|c|c|c|c|}
\hline & \multirow[t]{3}{*}{ Jenis bakteri } & \multicolumn{11}{|c|}{ Konsentrasi ekstrak (mg/mL) } \\
\hline & & \multicolumn{11}{|c|}{ Rata-rata $(\mathrm{mm}) \pm \mathrm{SD}$} \\
\hline & & 120 & 100 & 80 & 70 & 60 & 50 & 40 & 30 & 20 & 10 & 5 \\
\hline \multirow[t]{2}{*}{1} & E.Coli & $13,71 \pm$ & 10,31 & $9,92 \pm$ & - & $9,46 \pm$ & - & 0 & - & 0 & - & - \\
\hline & & 0,83 & $\pm 0,48$ & 0,75 & & 0,47 & & & & & & \\
\hline \multirow[t]{2}{*}{2} & P. aeruginosa & $7,53 \pm$ & $6,42 \pm$ & 0 & - & 0 & - & 0 & - & - & - & - \\
\hline & & 0,18 & 0,38 & & & & & & & & & \\
\hline \multirow[t]{2}{*}{3} & P.mirabilis & - & - & - & $8,42 \pm$ & $7,50 \pm$ & $7,31 \pm$ & $6,71 \pm$ & $6,41 \pm$ & 0 & - & - \\
\hline & & & & & 0,38 & 0,26 & 0,16 & 0,10 & 0,07 & & & \\
\hline
\end{tabular}

Keterangan: kontrol antibiotik Ciprofloxacin $5 \mu \mathrm{g} / \mathrm{mL}$ menghasilkan zona hambat sebesar 16,23 $\pm 1,44$

Hasil penelitian terkait profil kromatografi ekstrak etanol daun bambu diketahui memiliki senyawa fenol, flavonoid, saponin dan triterpenoid. Menurut Noventi dan Carolia, 2016 fenol merupakan golongan senyawa yang bersifat desinfektan dan memiliki kemampuan sebagai antibakteri dengan mendenaturasi protein sel (Noventi dan Carolia, 2016). Ikatan hidrogen yang terdapat pada senyawa tersebut akan mempengaruhi permeabilitas di dinding sel dan membran sitoplasma sebab keduanya tersusun atas protein. Ketidakseimbangan makromolekul dan ion dalam sel akan menyebabkan sel menjadi lisis.

Flavonoid merupakan golongan senyawa yang memiliki kemampuan kerja sebagai antibakteri dengan menghambat pertumbuhan bakteri, dimana pada senyawa flavonoid dapat 
menyebabkan kerusakan permeabilitas dinding sel bakteri dan menghambat motilitas bakteri (Darsana, et al., 2012). Akibat terganggunya dinding sel, sel tidak dapat menahan tekanan osmotik internal yang dapat mencapai 5 sampai 20 atm. Tekanan ini cukup untuk memecah sel apabila dinding sel dirusak. Saponin bekerja sebagai senyawa antibakteri dengan cara menurunkan tegangan permukaan sehingga mengakibatkan naiknya permeabilitas atau kebocoran sel menyebabkan senyawa intraseluler keluar sel (Nuria, et al., 2009) protein, asam nukleat dan nukleotida keluar dari sel akhirnya bakteri akan mati. Sifat antibakteri dari saponin dapat melalui penurunan tegangan permukaan dinding sel (membranolitik), melalui komponen aktif senyawa saponin adalah aglikon yang mampu membentuk komplek dengan sterol pada dinding sel bakteri menyebabkan pembentukan single ion channel, dimana dengan terbentuknya single ion channel mampu menghambat aktivitas enzim yang berperan pada transport ion didalam kehidupan bakteri, dengan terhambatnya transport ion maka metabolisme terganggu (Hoffman, 2003). Menurut Rosyidah, 2010 melaporkan bahwa pertumbuhan bakteri E. coli dapat dihambat dengan baik oleh senyawa saponin pada kulit batang tumbuhan kasturi (Mangifera casturi) diketahui fraksi aktif mampu menghambat pada konsentrasi 10,3 $\pm 0,5 \mathrm{~mm}$ (Rosyidah et al., 2010). Oleh Jaya, 2010 yang telah mengisolasi senyawa saponin dari akar putri malu diketahui mampu menghambat pertumbuhan bakteri $E$. coli (Jaya, A., 2010).

Senyawa terpenoid dapat bersifat sebagai antibakteri melalui aksinya dengan protein transmembran pada membrane luar dinding sel, dimana terbentuk ikatan kuat dari senyawa terpenoid dengan protein transmembran yang menyebabkan permeabilitas dinding sel berkurang sehingga pertumbuhan bakteri terhambat dan mati (Rachmawati, et al., 2011). Menurut penelitian lain fraksi dengan kandungan triterpenoid rimpang temu putih dengan konsentrasi $1000 \mathrm{ppm}$ mampu memberikan zona hambat sebesar $8 \mathrm{~mm}$ untuk bakteri $E$. coli (Rita, 2010).

\section{Kesimpulan}

Berdasarkan hasil uji yang telah dilakukan dapat disimpulkan bahwa kandungan metabolit sekunder yang terdapat pada ekstrak etanol daun bambu adalah flavonoid, fenol, saponin, dan triterpenoid. Selain itu ekstrak etanol daun bambu terbukti berpotensi menghasilkan aktivitas antibakteri terhadap bakteri patogen gram negatif isolat pasien luka diabetes

\section{Ucapan terimakasih}

Ucapan terima kasih kepada dana riset RISTOJA (Riset Tanaman Obat dan Jamu) Kementerian Kesehatan Tahun 2016 dan DIPA Fakultas Kedokteran Tahun 2017. 


\section{Daftar pustaka}

Alfian, R., \& Susanti, H. (2012). Penetapan Kadar Fenolik Total Ekstrak Metanol Kelopak Bunga Rosella Merah (Hibiscus Sabdariffa Linn) dengan Variasi Tempat Tumbuh secara $\begin{array}{lll}\text { Spektrofotometri. } & \text { Pharmaciana, 2(1), }\end{array}$ doi:http://dx.doi.org/10.12928/pharmaciana.v2i1.655

Annafiatuzakiah, A., Fajriyaty, I., \& Sari, R. (2017). Studi Etnofarmakologi, Toksisitas Akut dan Analgesik Ekstrak Etanol Daun Bambu (Bambusa vulgaris Schrad ex.J.C) Tanaman Endemik Kalimantan Barat.

Apridamayanti, P., \& Sari, R. (2019). Antibiotik Sensitivity Profiles Against Bacteria Isolates Which Infecting Patients With Diabetic Foot Ulcers Level 3 and 4 Wagner in Pontianak. European Journal of Biomedical and Pharmaceutical Sciences, 6(2), 83-88.

Darsana, I. G. O., Besung, I. N. K., \& Mahatmi, H. (2012). Potensi Daun Binahong (Anredera Cordifolia (Tenore) Steenis) dalam Menghambat Pertumbuhan Bakteri Escherichia Coli secara In Vitro. Indonesia Medicus Veterinus, 1(3), 337 - 351.

DepKes, R. I. (2000). Parameter Standard Umum Ekstrak Tumbuhan Obat. In.

Hanani, E. (2015). Analisis Fitokimia. Jakarta: EGC.

Harborne, J. B. (2006). Metode fitokimia: Penuntun Cara Modern Menganalisa tumbuhan. Bandung: ITB Press.

Hoffman, D. (2003). Medical Herbalism: The Sciences and Practice of Herbal Medicine (I. Tradition/Bear Ed.): Simon and Schuster.

ICMR (2009) Detection of Antimicrobial Resistence in Common Gram Negative and Gram Positive Bacteria Encountered in Infections Deseases- An Update', ICMR Bulletin: 39

Jaya, A. M. (2010). Isolasi dan uji efektivitas antibakteri senyawa saponin dari akar putri malu (mimosa pudica). (1), Universitas Islam Negeri Maulana Malik Ibrahim, Malang.

Macherla, S., Sabat, M., Sharadanalla, S., Venkateshwarlu, G., \& Rajeshwari, E. (2012). Evaluation of Anti-microbial Activity of Bambusa vulgaris Leaves. International Journal of Phytotherapy Research, 2(2), 36-39.

Mulyono, N., Lay, B. W., Rahayu, S., \& Yapriyanti, I. (2012). Antibacterial Activity of Petung Bamboo (Dendrocalamus Asper) Leaf Extract Against Pathogenic Escherichia coli and Their Chemical Identification. International Journal of Pharmaceutical \& Biological Archive, 3(4), 770-778.

Noventi, W. R. \& Carolia, N. (2016) Potensi Ekstrak Daun Sirih Hijau (Piper betle L .) sebagai Alternatif Terapi Acne vulgaris The Potential of Green Sirih Leaf ( Piper betle L .) for Alternative Therapy Acne vulgaris. Medical Journal of Lampung University. 5(1), 140-145

Nuria, M. C., Faizatun, A., \& Sumantri, S. (2009 ). Uji Aktivitas Antibakteri Ekstrak Etanol Daun Jarak Pagar (Jatropha curcus L.) terhadap Bakteri Staphylococcus aureus ATCC 25923, Escherichia coli ATCC 25922, dan Salmonella typhi ATCC 1408. Mediagro: Jurnal Ilmuilmu Pertanian, 5(2), 26-37 doi:http://dx.doi.org/10.31942/md.v5i2.559

Rachmawati, F., Nuria, M. C., \& Sumantri, S. (2011 ). Uji Aktivitas Antibakteri Fraksi Kloroform Ekstrak Etanol Pegagan (Centella asiatica (L) Urb) Serta Identifikasi Senyawa Aktifnya. $\begin{array}{lllll}\text { Jurnal Ilmu Farmasi } \quad \text { F } & \text { Farmasi }\end{array}$ doi:http://dx.doi.org/10.31942/jiffk.v0i0.372

Rita, W. S. ( 2010). Isolasi, Identifikasi, dan Uji Aktivitas Antibakteri Senyawa Golongan Triterpenoid Pada Rimpang Temu Putih (Curcuma zedoaria (Berg.) Roscoe). Jurnal Kimia (Journal Of Chemistry), 4(1), 20-26.

Rosyidah, K., Nurmuhaimina, S. A., Komari, N., \& Astuti, M. D. (2010). Aktivitas Antibakteri Fraksi Saponin dari Kulit Batang Tumbuhan Kasturi (Mangifera casturi). Alchemy (Journal of Chemistry, 1(2), 53-103. doi:https://doi.org/10.18860/al.v0i0.1674

Sari, R., \& Apridamayanti, P. (2015). Identifikasi bakteri penghasil ESBL pada penderita ulkus diabetikum derajat III dan IV Wagner. Laporan Penelitian DIPA Universitas Tanjungpura, Pontianak. 
Sari, R., Apridamayanti, P., \& Puspita, I. D. (2018 ). Sensitivity of Escherichia coli bacteria towards antibiotiks in patient with diabetic foot ulcer. Pharmaceutical Sciences \& Research, 5(1), 19-24. doi:https://doi.org/10.7454/psr.v5i1.3649

Soegondo, S., Soewondo, P., \& Subekti, I. (2009). Penatalaksanaan Diabetes Melitus Terpadu. Jakarta Balai Penerbit FKUI.

Septiana, R. S. (2011) Identifikasi dan Uji Aktivitas Antibakteri Fraksi Teraktif Daun Sirih Merah (Piper crocatum Ruiz \& Pau). Skripsi. Universitas Sebelas Maret.

Wardayanie, N. I. A., \& Sitorus, Y. M. N. (2012). Potensi Antibakteri dari Vinegar Bambu Andong (Gigantochloa pseudoarundinaceae) dan Bambu Ampel (Bambusa vulgaris Schrad var. striata). Jurnal of Agro-Based Industry, 29(2), 11-12. doi:http://dx.doi.org/10.32765/warta\%20ihp.v2 
